\title{
Comparison of enzymically glucuronidated flavonoids with flavonoid aglycones in an in vitro cellular model of oxidative stress protection
}

David E. Stevenson • Janine M. Cooney •

Dwayne J. Jensen • Reginald Wibisono • Aselle Adaim •

Margot A. Skinner • Jingli Zhang

Published online: 2 July 2008

(C) The Society for In Vitro Biology 2008

Erratum to: In Vitro Cell.Dev.Biol.-Animal

DOI 10.1007/s11626-007-9072-y

In the last line of the caption for Figure 3, the last word "determinations)." was inadvertently omitted.

The last line should read: $\mathrm{H}_{2} \mathrm{O}_{2}$ under the same conditions was $52.2 \pm 5.4$ (mean of ten separate determinations).

The online version of the original article can be found at http://dx.doi. org/10.1007/s11626-007-9072-y

D. E. Stevenson $(\bowtie) \cdot J$. M. Cooney $\cdot$ D. J. Jensen

The Horticulture and Food Research Institute of New Zealand,

Private Bag 3123, Waikato Mail Centre,

Hamilton 3240, New Zealand

e-mail: dstevenson@hortresearch.co.nz

R. Wibisono $\cdot$ A. Adaim $\cdot$ M. A. Skinner $\cdot J$. Zhang

The Horticulture and Food Research Institute of New Zealand, Private Bag 92-169, Mt Albert,

Auckland, New Zealand 